\title{
NOTES ON THREE COMMON SPECIES OF MADREPORARIAN CORALS KNOWN AS: CARYOPHYLLIA SMITHI, CARYOPHYLLIA CLAVÚS, COENOCYATHUS DOHRNI
}

\author{
by \\ MAYA B. BEST \\ Zoological Museum, University of Amsterdam
}

"I think it is true to say that of all classes of animals the corals have suffered most injustice at the hands of zoologists by reason of their being studied as fragments and far from the site of their natural environment."

Jones, 1907.

\section{INTRODUCTION}

Of course the words of Jones, cited above this article do not only apply to corals, but at least in this group of animals many systematical changes must be introduced now that we obtain so many ecological data with the help of modern techniques.

The following will be a discussion of the value of some taxa in the subfamily Caryophyllinae, around which there has been discussion for nearly a century, and of their application to forms that have been dived up by myself, paying carefully attention to their habitat. The three species this article deals with are generally known as:

Caryophyllia smithi Stokes \& Broderip, 1828

Caryophyllia clavus Scacchi, 1835

Coenocyathus dohrni Döderlein, 1913

After ecological observations and the study of the different forms in the collected material, three systematical questions arose:

1. Do Caryophyllia smithi and Caryophyllia clavus form two species (LACAZE-DuthIErs, 1897; RossI, 1957) or are they just two varieties of one species (Duncan, 1873)?

2. Is Coenocyathus dohrni a synonym of Caryophyllia smithi (cf. Rossi, 1956, 1957)?

3. Does Coenocyathus dohrni correspond with the definition of the genus Coenocyathus?

\section{MATERIAL}

My material of the three species was chiefly collected by myself, by means of SCUBA-diving and dredging in the Mediterranean Sea and the Atlantic Ocean. The fieldwork was mainly carried out in the environs of Banyuls-sur-Mer, using facilities of Laboratoire Arago (Pyrénées Orientales), in 1965 and 1966, but also in Marseille (1967) and Roscoff (Brittany) in 1966. Besides this living material, dead specimens from Marseille (kindly sent to me by Mr. H. Zibrowius), Napels and the south coast of Brittany (collected by Mr. M. Glémarec), have been examined at the Zoological Museum, Amsterdam, and from Malta and different localities all around the British and Irish coasts at the British Museum (Natural History), London.

\section{SURVEY OF LITERATURE}

The two genera to which the species belong are quite well defined by Vaughan \& WeLls (1943) and by Allorteau (1952). A diagnosis of the genus Caryophyllia can be given as follows: Solitary, turbinate to subcylindrical, fixed on shells or rocks, septa of the second and third cycle exsert, pali opposite of third cycle in one crown, columella fascicularly formed by twisted trabecular laths.

The genus Coenocyathus is much like Caryophyllia, but forming small phaceloid colonies by extratentacular budding, the polyps usually losing organic connection. The pali are small, often very indistinct, the form of the columella is more capricious.

About the species, however, many controversies in literature are still existing.

The first to be mentioned was Caryophyllia smithi, by de la Bèche in 1828 from Tor Bay, Devon (England). The species name however was given by Stokes \& Broderip, with the description and drawings of a small Caryophyllia species with a broad base. 
In 1860 Gosse'mentions it again from Devon and Cornwall and gives a good description of the polyp.

Duncan (1873) considers this coral, common on the southwest coast of England, as a variety of the species Caryophyllia clavus, which was already known from the Mediterranean. $C$. clavus var. smithi has a broad base, contrary to the narrow base found in $C$. clavus, but "this is the only strong distinction between it and C. clavess." LACAZE-Duthrers (1897), however, classifies $C$. smithi as a distinct species also found in the Mediterranean. In his paper he gives an extensive description of the differences between C. smithi and C. clavus. The broad base and the more irregular structure should give $C$. smithi specific status.

C. clavus has first been described by ScAccir in 1835 as a conically formed Caryophyllia fixed on shells or stones with a narrow base. Heller (1868) mentions the species from Lizza (Italy).

DöDERLEIN (1913) reports the presence of $C$. clavus as well as $C$. smithi and introduces the new species Coenocyathus dohrni (found in the Golf of Naples).

JoubIN (1928) gives good descriptions with photographs of $C$. claves (although including one colony of Coenocyathus dohrni, that LACAZE-DuthIERS (1899) had collected at Port Vendres (Pyrénées Orientales) as C. clavus) and C. smithi, while Broch (1934) makes mention of Coenocyathus dohrni from the Adriatic Sea stressing its resemblance with $C$. clavus.

Picard (1952) compares C. smithi from the Atlantic with the Caryophyllia of shallow waters from the Mediterranean, warning that the latter should not be mixed up with the deep water coral C. clavus living only on shells and stones. He concludes that there is no difference at the species level between the two and proposes to regard them as varieties of one species, calling the one from the Mediterranean $C$. smithi var. meridionalis. In my opinion this variety is the same as the form described by Döderlein as Coenocyathus dohmi. Also Rossi (1957) maintains the two different species $C$. clavus and C. smithi, but she states explicitly that Coenocyathus dohrni is a synonym of $C$. smithi.

In 1962, PAX \& Müllen reported just the two species C. clavus and Coenocyathus dohrni from the Adriatic Sea. They describe the latter as a common, typical shallow water form of this area.

When REEs mentioned this controversy again in 1962, he summarized (because his article deals only with C. smithi from Great Britain) the problem as follows: "whether these and the colour differences that have been reported in the living animals are specific or merely ecophenotypic remains to be elucidated".

\section{RESULTS}

During five months of fieldresearch in Banyuls-surMer I was able to collect many data about the three corals in question. I observed them under water in their natural habitat in all zones between 1 and 50 meters and moreover I kept them alive in the laboratory for months.

The well-known form of $C$. clavus (fig. 1) with the small base fixed on shells or stones could be dredged at a depth of $60-70 \mathrm{~m}$ or deeper on sandy bottom. The polyps are brownish red to light brown, often with the zigzag-line around the mouth on the oral disc. The tentacles are very long (in proportion to the rest of their body), transparent and thin. The tentacle itself is knobbed with concentrated nematocyst batteries. The skeleton is rather fragile and built up very regularly, exactly as described in earlier articles.

At the depth of 50-30 m I saw these Caryophyllia's on rocks (fig. 2), the colour and habitus of the polyps remain the same, only the base with which the animal is fixed on the rock is broader and tighter; the regularity of the skeleton decreases, apparently depending on the roughness of the substrate and the movement of the water (cf. Gardiner, 1939).

Above $20 \mathrm{~m}$ they become rarer and they correspond with the description of C. smithi (fig. 3): low, irregular and with a broad base. The colour and form of the polyp still remain the same, so that it is easy to identify them under water immediately amidst Coenocyathus dohrni (fig. 4) which is quite abundant in shallow water $(20-1 \mathrm{~m})$; below $25 \mathrm{~m}$ this latter species does occur, but less frequently, their optimum is apparently above $25 \mathrm{~m}$. Schematically it can be formulated as follows: Coenocyathus dohrni outnumbers $C$. smithi (s.s.) by far in shallow water; in the transitional zone "clavus-smithi", Coenocyathus dohrni is already rare, the species remains of the same shape although usually larger, while in dredged material among hundreds of $C$. smithi var. clavus I never found a Coenocyathus dohrni. In both diving area's (above and below $25 \mathrm{~m}$ ) I did observe C. smithi (s.l.) living among Coenocyathus dohrni; so even when growing under the same ecological conditions the two species remain easily recognizable.

The colour and habitus of the polyp of Coenocyathus dohrni is completely different from the Caryophyllia's. It is brown, white or red and has much shorter tentacles. If one compares the skeletons of the specimens of Caryophyllia and Coenocyathus 

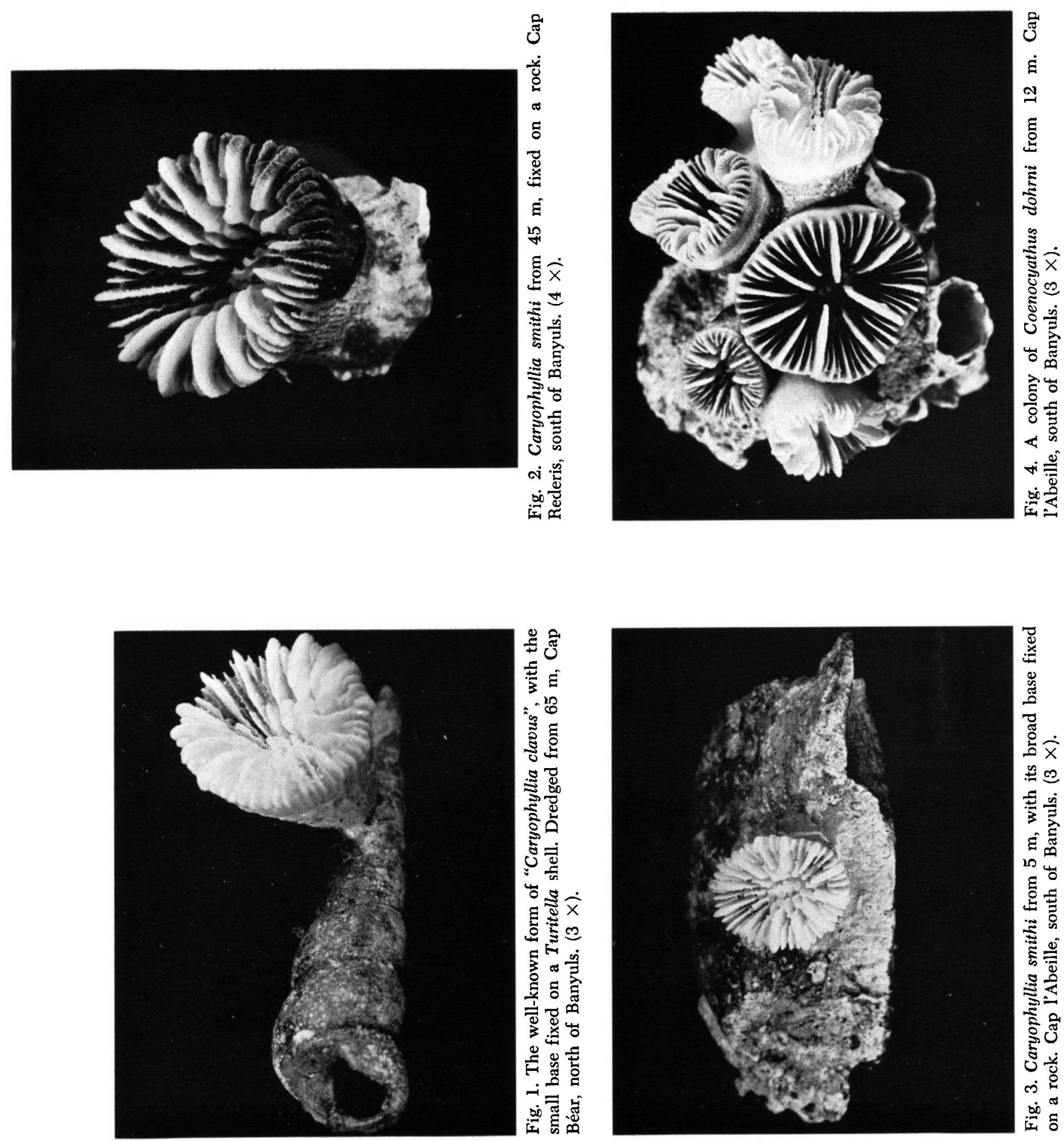

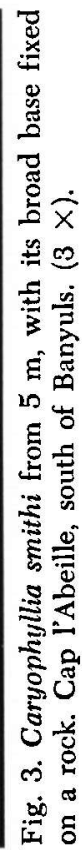




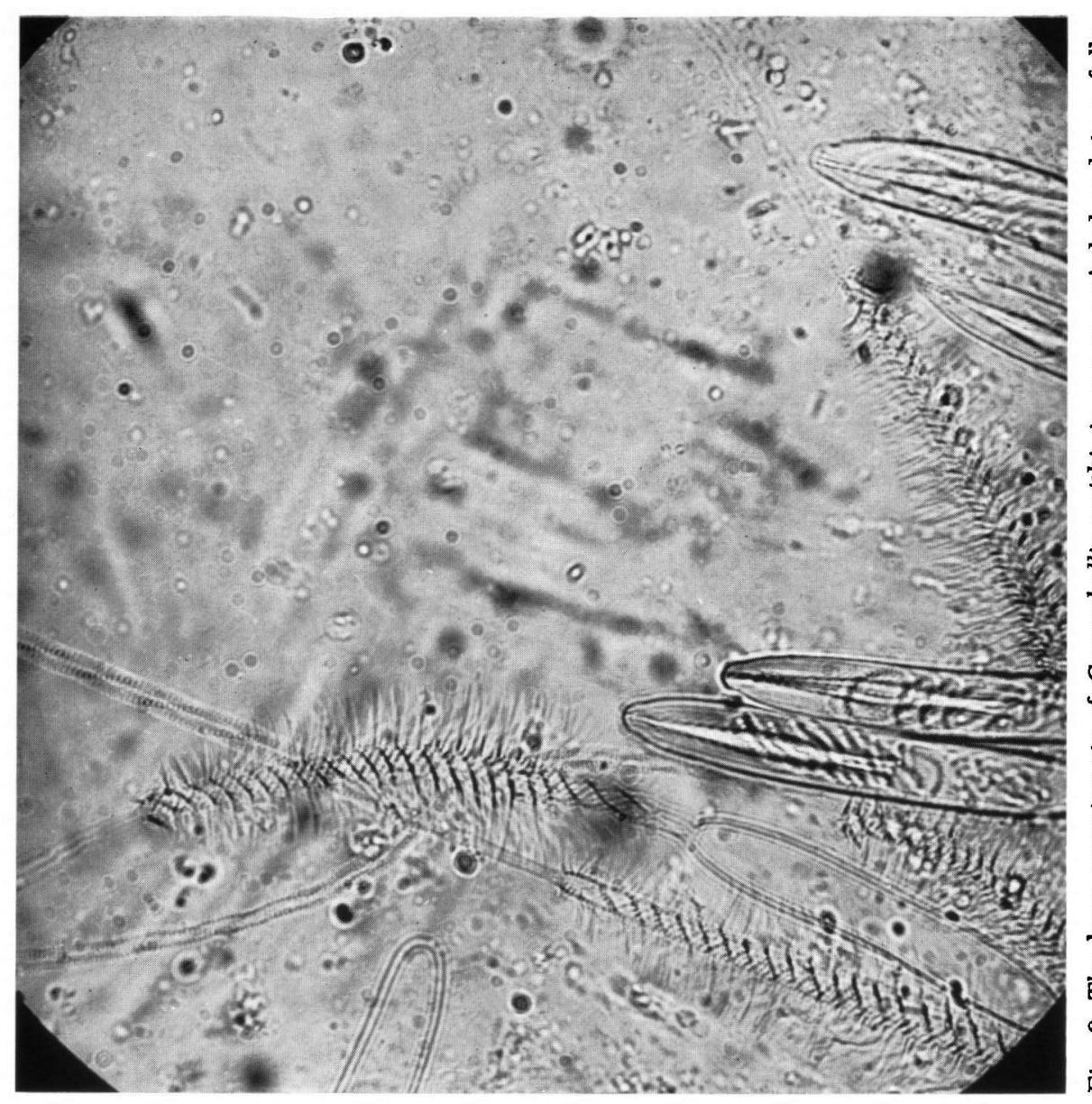

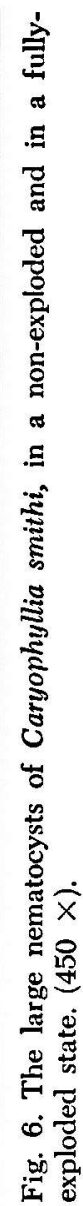

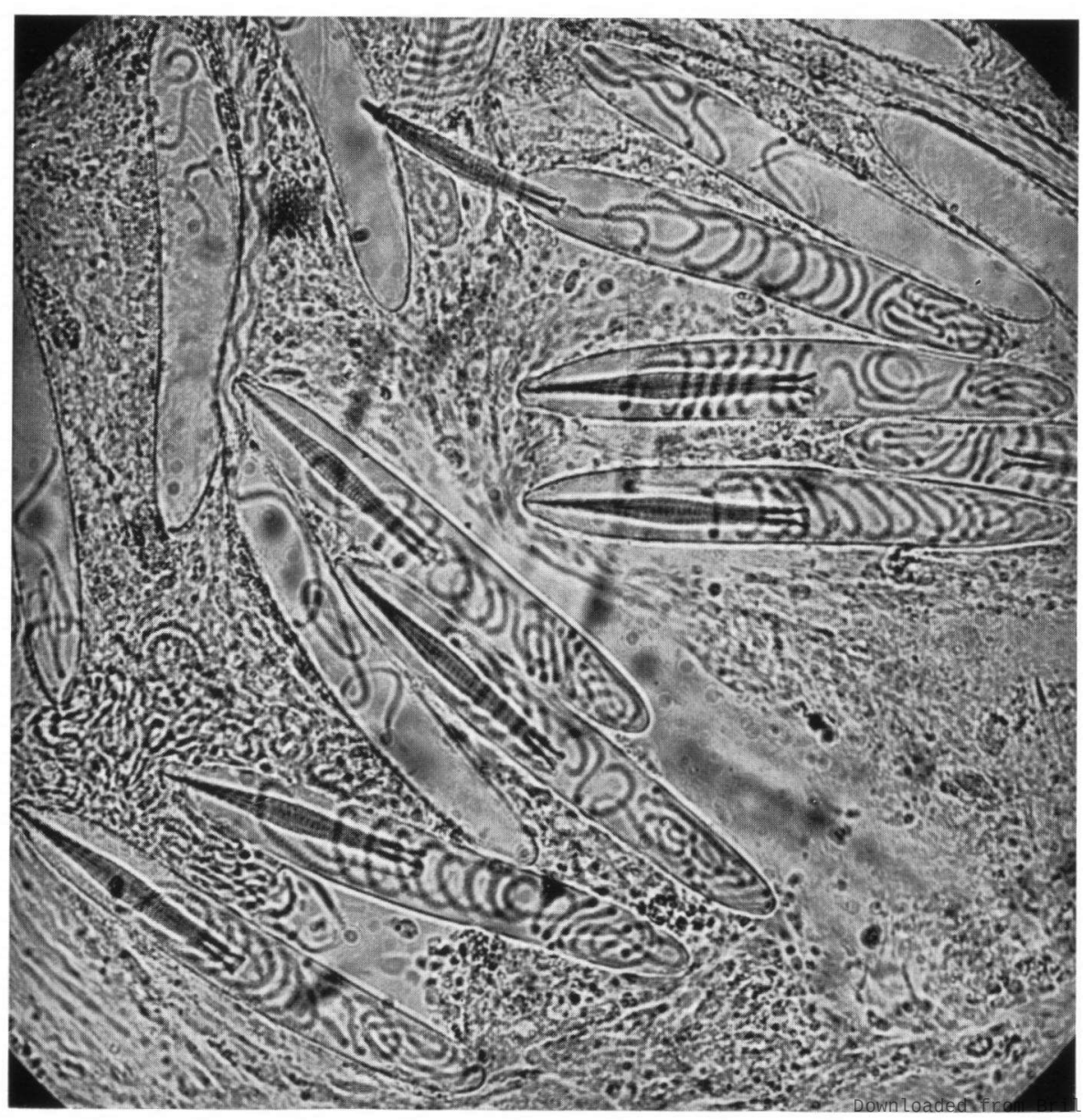

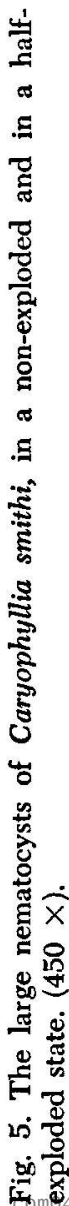


dohrni, distinguisable by their polyp, a correlated difference is found. They do indeed resemble each other, but after having observed various growthforms of both species, with their own ecological data, I have never been in doubt about the identification of the species, for generally speaking the pali and columella in Coenocyathus are smaller, the septa reach much farther in the fossa and the theca is smoother, not ribbed as the theca of C. smithi.

For the details of the skeleton structure of Coenocyathus dohrni I refer to the original description of Döderlein, because in later papers this species has often been mixed up with growthforms of $C$. smithi.

Coenocyathus dohrni is very common in the surroundings of Banyuls; we find it mostly living in groups together, which is mainly the result of the scores of larvae they produce, fixing themselves close to their mother coral. Although WeLcs (1956) states that "colonial coralla may also be produced by the fixation of a number of planulae of the same species in such close proximity that they subsequently fuse together" it is not the same way of forming a colony as that of other Coenocyathus species (I saw live ones of $C$. mouchezi myself). If ever there exists intra- or extratentacular budding in this species, then the two polyps must soon loose their organic connection, so that it is difficult to distinguish this form from a fusing together of two larvae. This species shows clearly the difficulty to formulate a definition of the idea "colony" within this group of animals. So if one considers the result of this way of growing as a colony, one could refer the taxon dohrni to Coenocyathus, but if the differences between a pseudocolony and a colony in the classical sense are stressed, Coenocyathus dohrni could equally well be included in Caryophyllia.

As for the nematocysts no differences could be found with C. smithi. In both species very large nematocysts do exist in the mesenterial filaments. It is known (WeLl, 1930; Carlgren, 1949) that several types of nematocysts are present within the same animal and it is difficult therefore to use them as a systematical characteristic. In both species there are three types of the size $0.03-0.05 \mathrm{~mm}$ (in length), the large nematocysts (fig. 5-6) are about $0.13 \mathrm{~mm}$ in length. Anyway the appearance of Coenocyathus dohrni in colonial connection together with the differences in skeleton structure mentioned earlier, do distinguish this coral from C. smithi.

To expand this conclusion geographically, the underwater caves near Marseille were inspected by me by diving twice to see the species Coenocyathus dohrni and C. smithi. The coral fauna in these caves
(Grotte de Jarre - Grotte de Moyade) is very rich. The species Coenocyathus dohrni is abundant, but not at all different from the ones $I$ observed in the surroundings of Banyuls. And really, at a depth of $12 \mathrm{~m}$ in Grotte de Jarre I found a C. smithi living among many Coenocyathus dohrni, with all the characteristics described above.

Apart from the research in the Mediterranean I dived just once in Roscoff (Brittany) to see the Atlantic form of C. smithi in its natural environment. My conclusion that $C$. smithi from Roscoff is the same species as C. smithi (s.l.) from the Mediterranean, is based on the same reddish brown colour of the polyp and the similar structure of the skeleton. The structure of the specimens from the Atlantic is still more capricious, partly due to the tides, lacking in the Mediterranean, and partly to the commensal barnacle Pyrgoma anglicum Sowerby, 1823, which is very often associated with the coral and influences its growth (REEs, 1962, 1966). The specimens that I could study from the other parts of the Mediterranean (Marseille, Naples, Malta) and Atlantic Ocean (South Brittany, British and Irish coasts) have only confirmed my opinion. Some specimens of $C$. smithi from a depth of $300 \mathrm{~m}$, in the collection of the British Museum (loc.: off Tory Island, N.W. Ireland), to which ReEs refers in his article (1962) and resembling in shape var. clavus (narrow base, fragile, fixed on a shell) even show that the narrow-based form is not exclusive for the Mediterranean, but is a growthform depending on ecological conditions.

I discussed the whole problem with Dr. Lucia Rossi (Museo di Zoologia, Torino) but do not agree with her that $C$. claves and $C$. smithi are two species and that Coenocyathus dohrni is a synonym of $C$. smithi. I admit that the Caryophyllia population between $1-20 \mathrm{~m}$ differs from that between $50-70 \mathrm{~m}$ (Rossi, in litt., 1967), but only by way of diving one can observe the slow transition from the one population into the other between $20-50 \mathrm{~m}$. The depths are given only approximately, because the growth-form depends also on other ecological factors as substrate and water movement. In the Atlantic one probably will find the same transition in growth-forms, but in zones, different from those I found in my diving area in the Mediterranean.

To solve a systematical problem of some corals with a widely ranging habitat, one has to work with specimens from which ecological data are known. In dealing with these corals I have chiefly based my opinion on the specimens with complete ecological data, which I have collected mostly myself. For one can only reconstruct a coral to its diagrammatical 
form, if the circumstances in which it has grown up, are known; otherwise one is describing growth-forms.

\section{CONCLUSIONS}

The three questions which are formulated in the introduction can now be answered as follows:

1. Caryophyllia clavus Scacchi is a growth-form of greater depth (less water movement) of the species Caryophyllia smithi Stokes \& Broderip, which has first been described from shallow waters, I suggest to call the form "smithi": Caryophyllia smithi St. \& Br., 1828, var. smithi St. \& Br., 1828 and the form "clavus": Caryophyllia smithi St. \& Br., 1828, var. clavus Scacchi, 1835.

2. Coenocyathus dohrni Döderlein is not a synonym of C. smithi, but a distinct species in view of the skeleton structure as well as the colour and shape of the polyp.

3. Within Coenocyathus, C. dohrni is characterized by its pseudo-colonies, which gives the species a rather isolated position. However, since the process leading to the formation of the colony is not yet fully understood, I prefer not to question the colonial nature and to include the species in Coenocyathus.

\section{SUMMARY}

During five months of fieldwork, mainly carried out in Banyuls-sur-Mer (Pyrénées Orientales), but also in Marseille and Roscoff (Brittany), the systematics and ecology of the madreporarian corals were studied, especially of the species. Caryophyllia smithi Stokes \& Broderip, 1828, Caryophyllia clavus Scacchi, 1835, and Coenocyathus dohrni Döderlein, 1913. Observation of these animals in their own environment gave an explanation of the different growth-forms within a species, which were formerly regarded as of specific importance. I did come to the conclusion that Caryophyllia clavus is a synonym of C. smithi. The species C. smithi has two growth-forms depending on some ecological data (depth, water movement, substrate): var. smithi and var. clavus. A slow transition from the one into the other was observed. Coenocyathus dohrni is not synonymous with C. smithi (cf. RossI, 1957); it is a species with specific characters in skeleton, shape of the polyp, and growth into a colony.

\section{BIBLIOGRAPHY}

Allorteau, J., 1952: Madréporaires Post-Paléozoïques. In: Piveteau, J., Traité de Paléontologie, T. 1, Protistes, Spongiaires, Coelentérés, Bryozoaires, pp. 539-684.

BÈCHE, H. T. DE LA, 1828: Notes on the habits of a Caryophyllia from Tor Bay, Devon. The Zool. J. III, Jan.Apr. $1828,481-485$.

BROCH, H., 1934: Beobachtungen an einigen adriatischen Seichtwasser-Anthozoen von Split. Biologia Generalis $\mathrm{XI}, 1-14$.

Carlaren, O., 1949: A survey of the Ptychodactiaria, Corallimorpharia and Actiniaria. K. Svensk. Vetensk. Akad. Handl. (4) 1. 1949, 1-121, pls. 1-4.

DöDERLEIN, L., 1913: Die Steinkorallen aus dem Golf von Neapel. Zool. Sta. Neapel Mitt. 21, 105-152, pls. 7-9.

Duncan, P. M., 1873: A description of the Madreporaria, dredged up during the expedition of H.M.S. Porcupine, (1869-1870). Tr. zool. Soc. London, Pt. 1, 8, 303-344, pls. $39-49$.

EDWARDS, M. \& J. HAIME, 1857: Histoire naturelle des coralliaires, 3 vol. texte, 1 vol. planches.

GARDiner, J. S., 1939: Madreporarian corals, with an account of variation in Caryophyllia. Discovery Repts., Cambridge, 18, 323-338.

Gosse, P. H., 1860: A history of the British sea-anemones and corals, 309-349. Van Voorst, Paternoster Row, London.

HeLleR, C., 1868: Die Zoophyten und Echinodermen des Adriatischen Meeres, Wien, 22-29.
JoNes, F. W., 1907: Growth forms and supposed species in corals. Proc. zool. Soc. London, 518-556.

Joubin, L., 1928: Faune et flore de la Méditerranée 9, 166, fig. 9. Siège à l'Inst. Océanogr. Paris, Secr. gén. 3, Ave. Octave Gréard.

LaCAZE-Duthiers, H. DE, 1897: Faune du Golfe du Lion. Arch. Zool. Exp. gén, 3me série, 5, 1-249.

- 1899: Les Caryophyllies de Port Vendres. Arch. Zool. Exp. gén, 3me série, 7, 529-562.

PAX, F. \& I. MüllLer, 1962: Faune et flore adriatica III, Die Anthozoenfauna der Adria, Split, 232-258.

PiCARD, J., 1952: Notes sur deux espèces de Madréporaires communes à la Manche et à la Méditerranée. Bull. Lab. Dinard 36, 5-7.

ReEs, W. J., 1962: The distribution of the coral Caryophyllia and the barnacle Pyrgoma anglicum in British waters. Bull. Brit. Mus. (Nat. Hist.) Zool. 8 (9), 401-418.

- 1966: Further notes on the distribution of the Caryophyllia smithi Stoker \& Broderip and Pyrgoma anglicum Sowerby. Ann. \& Mag. of Nat. Hist., Ser. 13, IX, 289-292, Apr.-June.

Rossi, L., 1956: Osservazioni ecologiche su alcuni Anthozoi del Golfo di Genova. Boll. Zool. Napoli 23, nr. 2, 237-246.

- 1957: Revisione critica dei Madraporarii del Mar ligure I, Doriana. Annali del Museo civico di Storia naturale “G. Doria" II, nr. 86, 1-9.

ScACcHI, A., 1835: Notizie intorno alle conchiglie ed zoo- 
fiti fossili che si trovano nella vicinanze di Gravino in Puglia. Ann. Civ. Reg. Due Sicilie 7, 1-18.

Stokes, L. \& W. J. BRoderuP, 1828: Note. Description of Caryophyllia smithi n.sp. The Zool. J. III, 485-486, pl. 13, fig. 1-6.

Vaughan, F. W. \& J. W. Wells, 1943: Revision of the suborders, families, genera of the Scleractinia. Geol. Soc. Am. special Papers 44.
WeILL, R., 1930: Essai d'une classification des Nématocystes des Cnidaires. Bull. Biol. France Belg. 64, 141153, pl. 1 fig.

Wells, J. W., 1956: Scleractinia. In: Moore, R. C., Treatise on Invertebrate Palaeonthology, Univ. of Kansas Press, Kansas, 328-443. 